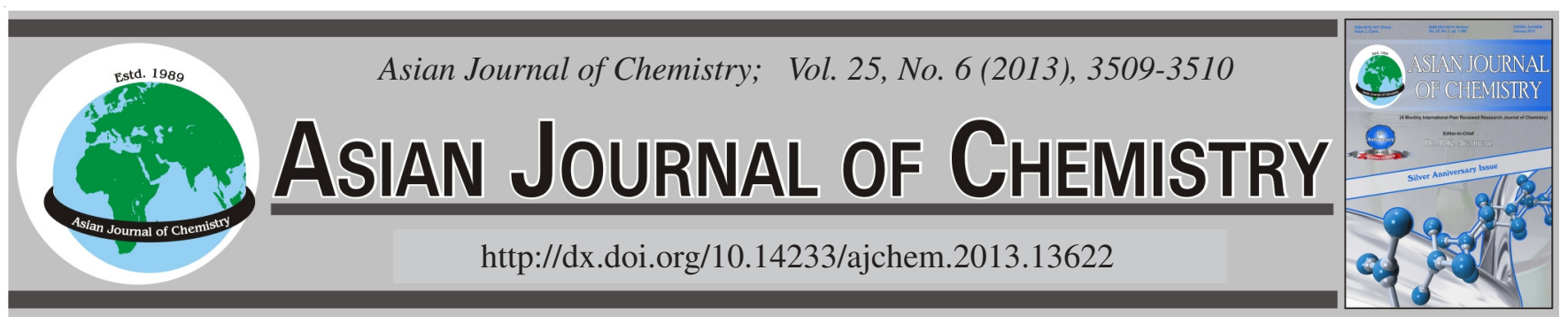

NOTE

\title{
Synthesis, Crystal Structure and Magnetic Property of a Sandwich-Like Cyanide-Bridged Fe(III)-Mn(II) Complex
}

\author{
Daopeng Zhang ${ }^{*}$, Zengdian Zhao and Xia Chen
}

College of Chemical Engineering, Shandong University of Technology, Zibo 255049, P.R. China

*Corresponding author: E-mail: dpzhang73@126.com

(Received: 18 February 2012;

Accepted: 28 December 2012)

AJC-12629

A trinuclear cyanide-bridged Fe(III)-Mn(II) complex has been synthesized with pyridine carboxamide trans-dicyanide iron building
block and structurally characterized as trinuclear sandwich-like, in which the two cyanide-containing building blocks acting as a monodentate
ligand were coordinated face to face to central Mn(II) ion. Investigation over its magnetic property reveals the antiferromagnetic magnetic
coupling between the cyanide-bridged neighboring Fe(III) and Mn(II) ions.
Key Words: Cyanide-bridged, Crystal structure, Magnetic property.

As one of the most important magnetic systems, cyanidebridged complexes have got much attention since their molecular topological structures and magnetic coupling nature between neighboring metal ions through the cyanide bridge can be relatively controlled and predicted ${ }^{1-3}$. Recently, we have reported some low-dimensional heterometallic cyanide-bridged magnetic complexes with various topological structures with a series of rigid trans-dicyanide-containning building blocks based on large in-plane pyridine carboxamide ligands ${ }^{4-7}$. Here, we present the synthesis and magnetic property of a sandwich-like cyanide-bridged Fe(III)-Mn(II) complex based on pyridine carboxamide trans-dicyanide iron building block.

To a solution of $\left[\mathrm{Mn}(\mathrm{acac})_{2}\right] \mathrm{Cl}(28.9 \mathrm{mg}, 0.1 \mathrm{mmol})$ in methanol $(10 \mathrm{~mL}), \mathrm{K}\left[\mathrm{Fe}(\mathrm{bpb})(\mathrm{CN})_{2}\right](46.5 \mathrm{mg}, 0.10 \mathrm{mmol})$ $\left[\mathrm{bpb}^{2-}=1,2-b i\right.$ ( (pyridine-2-carboxamido)benzenate $]$ dissolved in methanol/water (4:1, v:v) $(10 \mathrm{~mL})$ was carefully added. The resulting mixture was filtered at once and the filtrate kept undisturbed at room temperature. After several days, darkbrown block crystals were collected by filtration with the yield of $34.2 \mathrm{mg}, 60.4 \%$. Anal. calcd. (\%) for $\mathrm{C}_{48} \mathrm{H}_{56} \mathrm{Fe}_{2} \mathrm{MnN}_{12} \mathrm{O}_{12}$ : C, 48.82; H, 4.63; N, 14.85. Found (\%): C, 48.74; H, 4.68; N, 14.71 .

Elemental analyses of carbon, hydrogen and nitrogen were carried out with an Elementary Vario El. Variable-temperature magnetic susceptibility and field dependence magnetization measurements were performed on a Quantum Design MPMS SQUID magnetometer.
Structure determination: A suitable white block crystal with dimensions of $0.19 \mathrm{~mm} \times 0.23 \mathrm{~mm} \times 0.31 \mathrm{~mm}$ was mounted on a glass fiber and the data were collected on a Bruker Smart 1000 CCD diffractometer with a $\mathrm{MoK}_{\alpha}$ radiation $(\lambda=0.71073 \AA)$ at $293(2) \mathrm{K}$ by using an $\omega$ scan mode in the range of $1.60<\theta<25.01^{\circ}$. The hydrogen atoms bound to carbon were located by geometrically calculations and their positions and thermal parameters were fixed during the structure refinement. All non-hydrogen atoms were refined by full-matrix least-squares techniques. All calculations were performed by the SHELXTL 97 program $^{8}$. Crystallographic data and experimental details for structural analyses are summarized in Table-1. CCDC: 864012.

In the sandwich-like complex, two $\left[\mathrm{Fe}(\mathrm{bpb})(\mathrm{CN})_{2}\right]^{-}$units, acting as a monodentate ligand, connect the central $\mathrm{Mn}$ (II) ion coordinated by the additional four oxygen atoms coming from four solvent methanol molecules. The coordination sphere for the $\mathrm{Mn}$ (II) atom is a octahedron, in which four equatorial positions are occupied by four oxygen atoms from the coordinated methanol molecules and the other two axial ones come from the nitrogen atoms of the bridging cyanide groups. As shown in Table-2, the distances between the Mn atom and the $\mathrm{O}$ atoms of the solvent molecules are 2.2042(19) and 2.2191(19) $\AA$, while the Mn-N cyanide bond lengths are 2.159(2) $\AA$, giving further information about the slightly distorted octahedron surrounding of the $\mathrm{Mn}(\mathrm{II})$ ion. The angle of $\mathrm{C} 1 \equiv \mathrm{N} 1-\mathrm{Mn} 1$ is $164.3(2)^{\circ}$, indicating that these three atoms deviate slightly from a linear configuration. 


\begin{tabular}{ll}
\hline \multicolumn{1}{c}{ TABLE-1 } \\
\multicolumn{1}{c}{ CRYSTALLOGRAPHIC DATA AND STRUCTURE } \\
REFINEMENT SUMMARY FOR THE COMPLEX \\
\hline Empirical formula & $\mathrm{C}_{46} \mathrm{H}_{52} \mathrm{Fe}_{2} \mathrm{MnN}_{12} \mathrm{O}_{12}$ \\
Formula weight & 1131.64 \\
Temperature $(\mathrm{K})$ & $293(2)$ \\
Wavelength $(\AA)$ & 0.71073 \\
Crystal system, space group & Monoclinic, $\mathrm{P} 2(1) / \mathrm{n}$ \\
Unit cell dimensions $(\AA)$ & $\mathrm{a}=8.6044(13), \mathrm{b}=11.7587(17)$, \\
Volume $\left(\AA^{3}\right)$ & $\mathrm{c}=25.426(4)$ \\
Z, Calculated density $\left(\mathrm{mg} / \mathrm{m}^{3}\right)$ & $2571.8(7)$ \\
Absorption coefficient & $2,1.461$ \\
$\mathrm{~F}_{(000)}$ & 0.870 \\
Reflections collected/unique & 1170 \\
Data/restraints/parameters & $18287 / 4494\left[\mathrm{R}_{\text {(int) }}=0.0329\right]$ \\
Goodness-of-fit on $\mathrm{F}^{2}$ & $4494 / 0 / 334$ \\
Final $\mathrm{R}$ indices [I $>2 \sigma(\mathrm{I})]$ & 1.044 \\
$\mathrm{R}$ indices $($ all data) & $\mathrm{R}_{1}=0.0332, \mathrm{wR}_{2}=0.0824$ \\
Largest diff. peak and hole $\left(\mathrm{e} / \AA^{3}\right)$ & $\mathrm{R}_{1}=0.0444, \mathrm{wR}_{2}=0.0897$ \\
\hline
\end{tabular}

The temperature dependence of magnetic susceptibility for the complex measured in the temperature range of 2-300 $\mathrm{K}$ in the applied field of $2000 \mathrm{Oe}$ is given in Fig. 1. The room temperature $\chi_{\mathrm{m}} \mathrm{T}$ values of the complex is $5.13 \mathrm{emu} \mathrm{K} \mathrm{mol}^{-1}$, which is consistent with the spin only value of $5.125 \mathrm{emu} \mathrm{K}$ $\mathrm{mol}^{-1}$ for uncoupled $\mathrm{Mn}(\mathrm{II})(\mathrm{S}=5 / 2)$ and two low spin $\mathrm{Fe}(\mathrm{III})$ $(\mathrm{S}=1 / 2)$ based on $\mathrm{g}=2.00$. With the temperature decreasing, the $\chi_{\mathrm{m}} \mathrm{T}$ value decreases gradually and attains the value of $4.95 \mathrm{emu} \mathrm{K} \mathrm{mol}{ }^{-1}$ at $c a .50 \mathrm{~K}$, then decreases sharply to their lowest value of $2.46 \mathrm{emu} \mathrm{K} \mathrm{mol}^{-1}$ at $2 \mathrm{~K}$. This is characteristic of antiferromagnetic coupling in the trimeric $\mathrm{Fe}(\mathrm{III})_{2} \mathrm{Mn}(\mathrm{II})$ cluster, which is also proven by the Brillouin curves (Fig. 1). The magnetic susceptibility for the complex conforms well to Curie-Weiss law in the range of $2-300 \mathrm{~K}$ and give the negative Weiss constant $\theta=-3.27 \mathrm{~K}$ and Curie constant $\mathrm{C}=5.18 \mathrm{emu}$ $\mathrm{K} \mathrm{mol}^{-1}$.
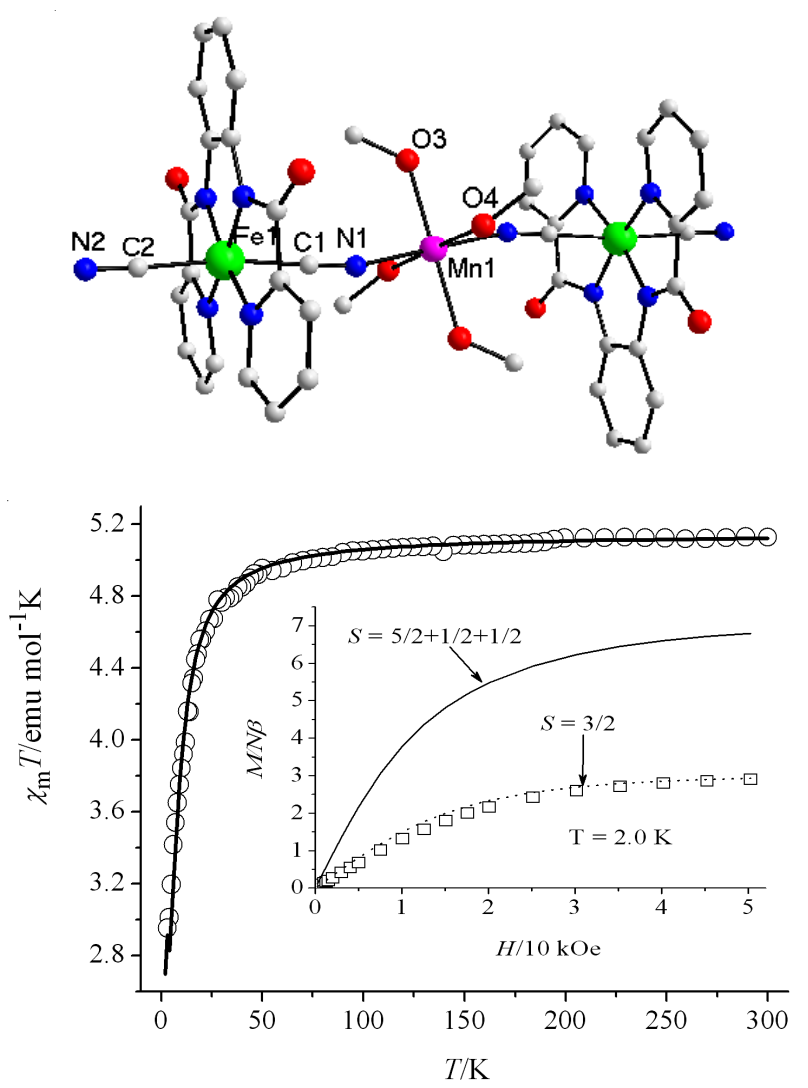

Fig. 1. Trinuclear structure of the complex and its magnetic property

\section{ACKNOWLEDGEMENTS}

This work was supported by the Science and Technology Project of High Education, Shandong Province (No. J11LB09) and the Natural Science Foundation of Shandong Province (ZR2011BM008) and the Young Teacher's Support and Development Plan of Shandong University of Technology.

TABLE-2

SELECTED BOND LENGTHS ( $(\AA)$ AND ANGLES $\left(^{\circ}\right)$ FOR Fe(III)-Mn(II) COMPLEX

\begin{tabular}{|c|c|c|c|c|c|}
\hline Bond & Dist. & Bond & Dist. & Bond & Dist. \\
\hline Mn1-N1 & $2.159(2)$ & $\mathrm{Mn} 1-\mathrm{O} 3$ & $2.2042(19)$ & Mn1-O4 & $2.2191(19)$ \\
\hline Fe1-C1 & $1.972(2)$ & $\mathrm{Fe} 1-\mathrm{C} 2$ & $1.979(2)$ & Fe1-N3 & $1.8962(19)$ \\
\hline Fe1-N4 & $1.8850(19)$ & Fe1-N5 & $1.995(2)$ & Fe1-N6 & $1.9976(19)$ \\
\hline Angle & $\left({ }^{\circ}\right)$ & Angle & $\left({ }^{\circ}\right)$ & Angle & $\left({ }^{\circ}\right)$ \\
\hline Mn1-C1-N1 & $164.3(2$ & $\mathrm{C} 1-\mathrm{Fe} 1-\mathrm{C} 2$ & $172.25(10)$ & Fe1-C1-N1 & $178.6(2)$ \\
\hline
\end{tabular}

\section{REFERENCES}

1. J.N. Rebilly and T. Mallah, Struct. Bond, 122, 103 (2006).

2. R. Lescouezec, L.M. Toma, J. Vaissermann, M. Verdaguer, F.S. Delgado, C. Ruiz-Perez, F. Lloret and M. Julve, Coord. Chem. Rev., 249, 2691 (2005).

3. H. Miyasaka, A. Saitoh and S. Abe, Coord. Chem. Rev., 251, 2622 (2007).

4. Z.H. Ni, H.Z. Kou, L.F. Zhang, C. Ge, A.L. Cui, R.J. Wang, Y. Li and O. Sato, Angew. Chem. Int. Ed., 44, 7742 (2005).
5. Z.H. Ni, H.Z. Kou, Y.H. Zhao, L. Zheng, R.J. Wang, A.L. Cui and O. Sato, Inorg. Chem., 44, 2050 (2005).

6. Z.H. Ni, L.F. Zhang, V. Tangoulis, W. Wernsdorfer, A.L. Cui, O. Sato and H.Z. Kou, Inorg. Chem., 46, 6029 (2007).

7. D.P. Zhang, H.L. Wang, Y.T. Chen, Z.H. Ni, L.J. Tian and J.Z. Jiang, Inorg. Chem., 48, 5488 (2009).

8. G.M. Sheldrick, SHELXTL97, Program for the Refinement of Crystal Structure, University of Göttingen, Germany (1997). 